\title{
ITMA-ASIA+CITME2008 一合緎機械
}

\author{
阿部一良 ABE Kazuyoshi, 辻 広治 TSUJI Koji \\ TMTマシナリー株式会社
}

\section{1. 紡糸 · 巻取機}

ITMA-ASIA は，開催地が合成繊維機械のメインマー ケットである，中国上海とあって，各ブースへの訪問客 も多く，活気があった。主要出展メーカーは，ヨーロッ パ勢数社，中国勢数社，日本から1社であった。

紡糸システムについては, 各社パネル展示のみであっ たが，省エネ，高付価值を謳った環状冷却システムが多 く見られた。

長繊維巻取設備については，TMTと Barmagが，次 期設備のコンセプトを持った製品を室内展示して，ユー ザーにのみ公開していた。中国メーカーは，両社既存製 品に類似した製品を出展するに過ぎなかった。中国メー カーと両社の技術レベルには数年の隔たりがあると思わ れるが，中国メーカーの技術追従が早くなってきている ことに脅威を感じた。

以下，主要各メーカーの展示について報告する。

\subsection{TMTマシナリー (日本)}

「No.1から ONLY-ONEへ」をテーマに2機種を出展. 新型スパンデックスワインダーATi- $459 \alpha$ （図 1）を巻 き返し実演展示. MTC (Motion Traverse Control:トラ バースのフリーレングスを変化させてパッケージの巻き 幅を任意に制御する機能）による自在なパッケージ形状 の形成を実演していた。

世界最長最小径ボビンホルダー（1800mm 申 110mm）

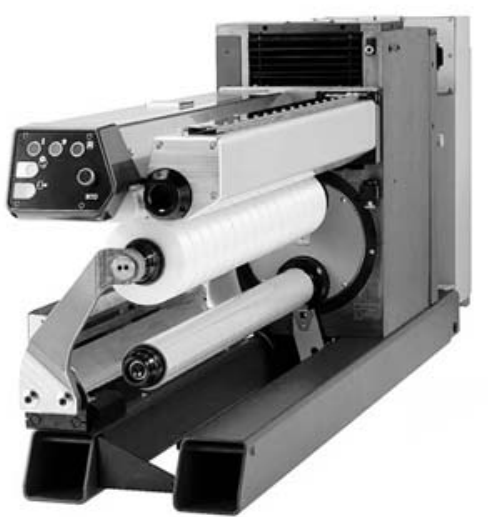

图1 ATi-459 $\alpha$

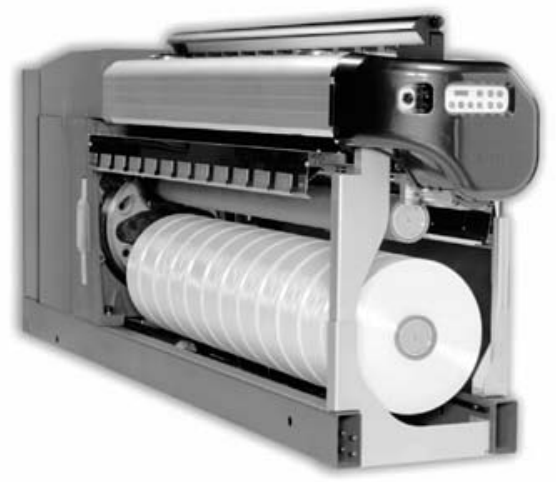

図2 ORCA

の新型ワインダーATi-418R12 ORCA（図2）を，ユーザ 一のみを対象として別室に展示. CIQ（Circular Inflow Quench: 環状クエンチシステム) は幅広い高品質な糸品 種に対応しており, 冷却風の大幅削減により省エネの実 現をアピールしていた。この ORCAと CIQ との組み合 わせにより, High-Multi 糸を従来と同スペースで省エネ かつ生産量 2 割アップを実現可能としている. その他, 既に量産体制にあるATi-614MR/24（24 end 4 本ボビン ホルダーワインダー）の生産工場での実動状況をビデ オ展示し，産資設備・衣料用設備についてはCIQ+ATiシリーズをパネル展示していた。

\subsection{OERLIKON BARMAG（ドイツ）}

衣料用ワインダーでは，I-QOON（24 end 4本ボビン ホルダーワインダー）を実機展示（図3）。

ITMA2007で別室展示していた，フレームレスPOY Winder WINGS（図4）は今回もユーザーのみを対象と した別室展示であった。

パネル展示による細物産資（250-500 d）設備のシス テム提案と, Hot rollの実機展示を行っていた.

i-QOON 24end 機ワインダー仕様

·系管径 $\times$ 満貫径： $\Phi 110 \times \Phi 440 （ \mathrm{~mm})$

・ボビンホルダー長： $2 \times 1380 \mathrm{~mm} \times 2$

・巻取速度：2500～6000 ( $\mathrm{m} / \mathrm{min})$

1.3 OERLIKON NEUMAG（ドイツ）

シンプル，ウエストレス，高速，高効率を追求した 


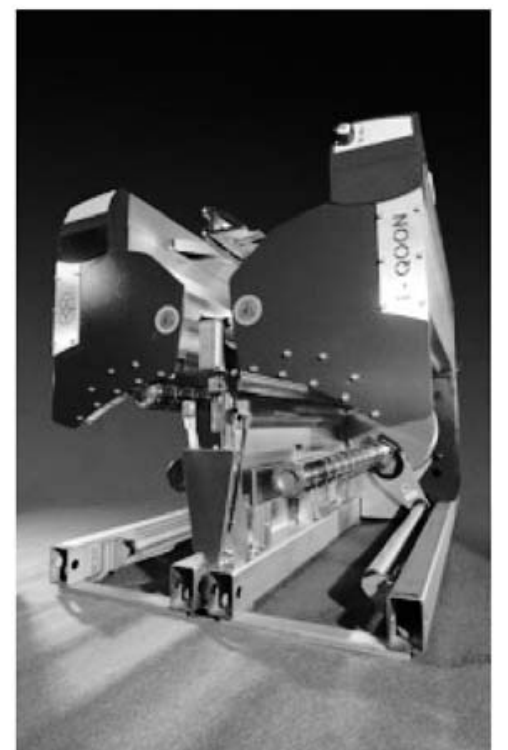

図3 i-QOON

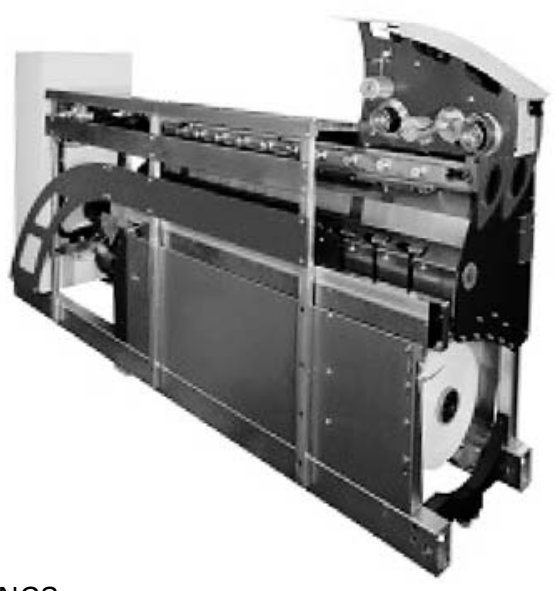

图4 WINGS

1end-BCF生産設備“SYTEC ONE”を展示していた。

1.4 SWISSTEX WINTERTHUR AG（スイス）

BCF（symTTex M20,T20）設備用ワインダー（FW11 型）とTEXTURING NOZZLEを展示していた。 SPINNING-BEAM 12end型にて，3色コーミングル対 応の左右対称フレーム構成で，2ワインダー 4 end 巻取設 備であった。

1.5 LURGIZIMMER（ドイツ）

STAPLE-FIBERの SPINNING-BEAM 2end機と筒状 QUENCHを展示していた.コンパクトなRING SPINNERET SYSTEM として $600 \mathrm{~mm}$ のSPINNINGピッチを紹介.

\subsection{COMOLI（イタリア）}

M250-900 16end スパンデックスワインダーを展示.

\section{7 上海金緯化繊維機械製造（JWELL）}

$1500 \mathrm{~mm}$ ボビンホルダーのハネトラバース機（図5), カムトラバース機（図6）を実機展示. いずれの機種も 欧州，日本メーカーの製品に酷似している.

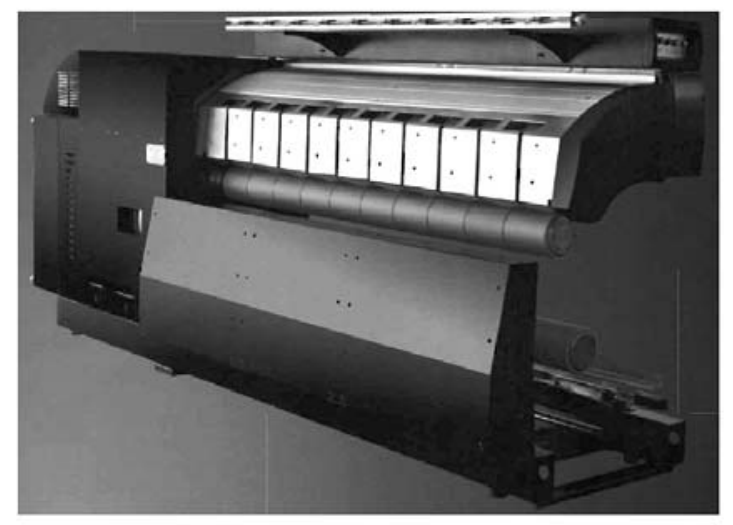

図5 JWAR15

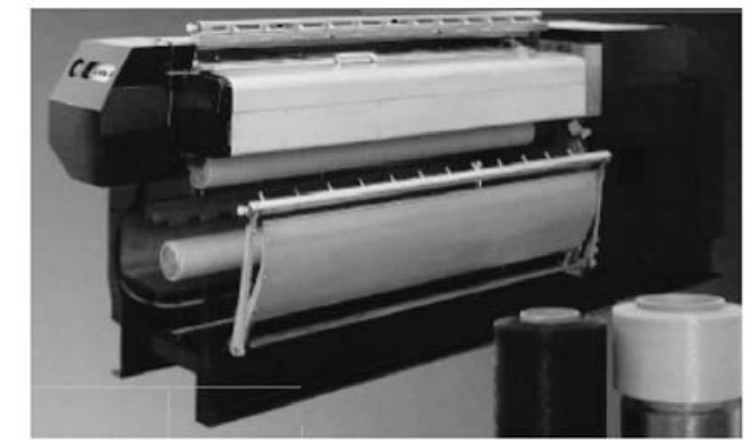

図6 JWA15

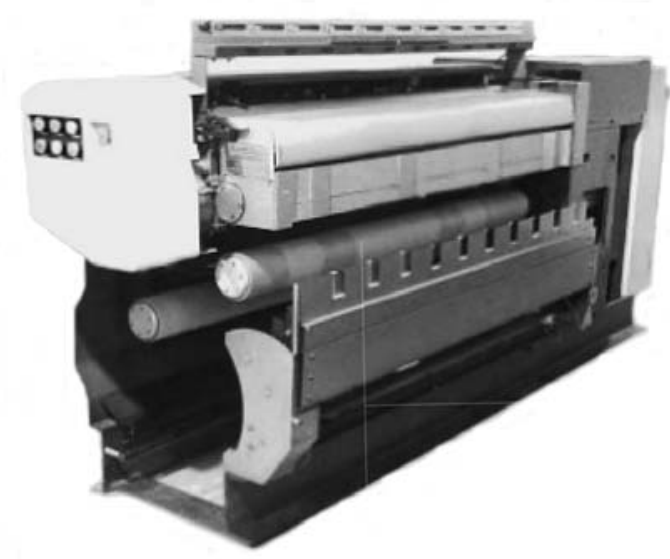

図7 ZWB620

1.8 鄭州纺织机械股份有限公司 (ZZFJ)

日本メーカーの類似ワインダーを $20 \mathrm{end}$ 機で展示. 既 存機の多end化改造をアピール（図7）.

1.9 太平洋機械 (PACIFIC)

中国メーカー唯一の独自デザインでの $10 \mathrm{end} 1500 \mathrm{~mm}$ ボビンホルダー ハネトラバース機を展示（図8).

\subsection{0 北京中麗化繊機械 (CTAMP)}

欧州メーカー類似の 24 end 4 本ボビンホルダーワイン ダーを展示. BWAT-55110（図9）

A.R.Q.という名称で各錐の外周から内側に向かって単 糸冷却する紡糸システムをパネル展示していた. 


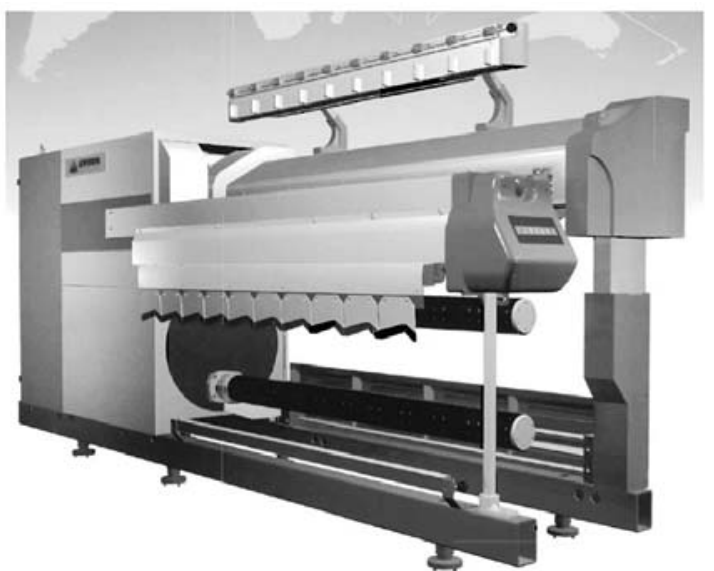

图8 TCTQ298

\subsection{1 大連合成繊維研究所（DSFRI）}

C.B.Q. (CENTRAL BLOWING QUENCHING SYSTEM)

という名称で各錐中央の内側から外側に向かって単糸を 冷却する紡糸システムをパネル展示.

\subsection{2 その他}

【ゴデットロール】

RETECH，ISGEVがHot rollを実機展示，DIENESは パネル展示のみ。各社，ITMA2007同等またはスケール ダウンした展示内容であった.

\section{【制御機器】}

安川電機が繊維専用インバーターT1000を展示してい た。

数社の中国メーカーが，オリジナルインバータを展示 していた。

\section{2. 加工機}

仮撚加工機は日本企業 1 社，（TMTマシナリー /パネ ル展示のみ), 欧州企業 2 社（BARMAG，DIUDICI）中 国企業 3 社，（宏源，海源，越剣） AIR加工機は欧州企 業1社（SSM），日本企業1社(AIKI)で出展されていた。

今回 $\mathrm{IAD}$ (単錘自動ドッファー) 付き自動機の展示は 1 社のみであったが，スパンデックスの混繊加工，ナイ ロン仕様機台や T型レイアウトの展示機が複数みられ, 各社とも中国市場の特徵を視野に入れており，自動化よ りも多品種対応への柔軟性に重点を置いていたように感 じられた．特筆すべき新技術や新要素の発表を行った企 業はなかったが，上海での開催ということもありコスト や効率重視の中国市場を意識した内容で，全体として中 国メーカーの追従が強く感じられる展示会であった。

以下，各社の展示について報告する

\section{【仮撚加工機】}

\subsection{TMT マシナリー（日本）}

パネル展示にて独自技術であるクアトロニップ（図

10）を紹介していた。これは細デニールハイカウント糸
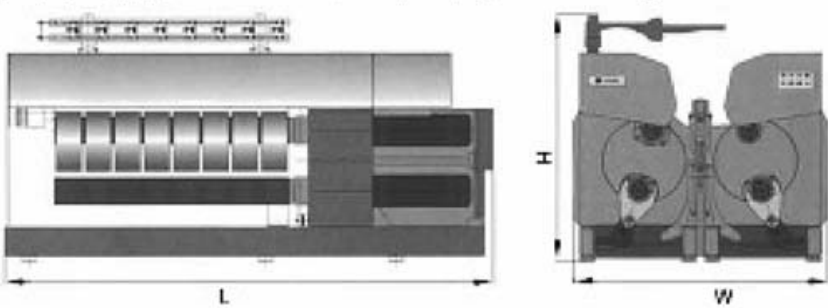

図 9 BWAT-55110

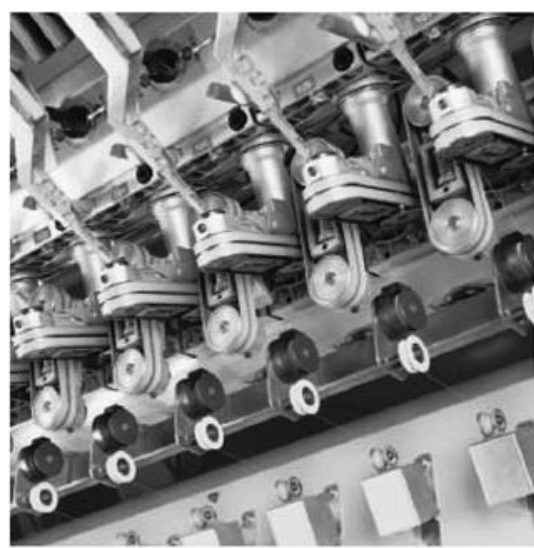

図10 クアトロニップ

加工で従来のニップッイスターより高速で加工できるこ とを特徵としている，パネル中央のモニターではニップ ベルト交換の様子や従来ニップと比較しての糸加工の優 位性などをアピールするビデオ上映を行い，注目を集め ていた。

\subsection{OERLIKON BARMAG（ドイツ）}

$\mathrm{eFK}$ の片側 $\mathrm{V}$ 型 12 錘機を展示していた。既に発表済 みのCoCoonに搭載されたゴデットローラーを小径化 し，タンゼンシャル駆動のフリクションユニット，パイ プ式クーリング装置などのデバイスを組み合わせ，生産 性や操作性，省エネなどをアピールした機台としてまと められている。1次ヒーター長は $1.5 \mathrm{~m}$ の熱媒式で 15 デ ニール以下主体の細物専用機. ドッフィングはマニュア ル仕様で中国市場向けのローコストマシンであり，どこ まで中国市場に受け入れられるかが注目される。

\subsection{GIUDICI（イタリア）}

T型片側 24 鍾機を展示していた。機種はTG30AE（図 11). 展示機の中では唯一の IAD 機であり第2フィード ローラーの下で1スパンはゴデットピンヒーター仕様, 他の1スパンではスパンデックスの混繊加工を行ってい た. 1 次ヒーターは 4 錘 $1 \mathrm{BOX}$ の熱媒ヒーターを使用し ており，T型ながら糸掛けには 2 名の作業者が必要。ナ イロン機仕様ということで巻幅は8インチ仕様となって いた. $\mathrm{IAD}$ 仕様もさることながら出展機中では最もハイ スペックなマシンである. 


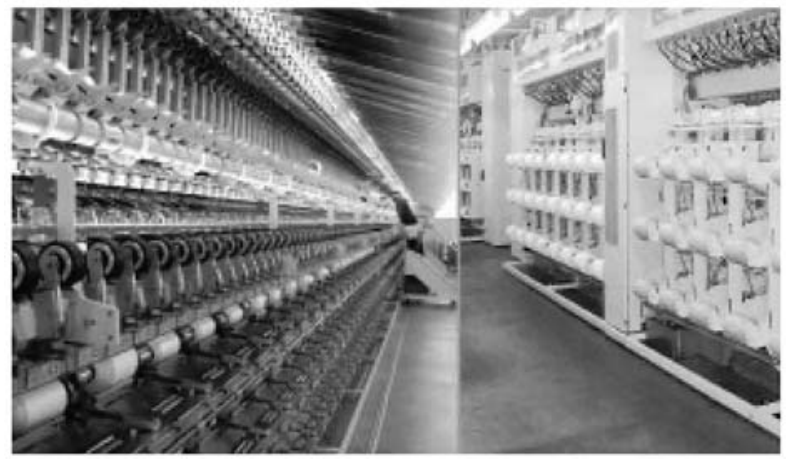

图 $11 \mathrm{TG} 30 \mathrm{AE}$

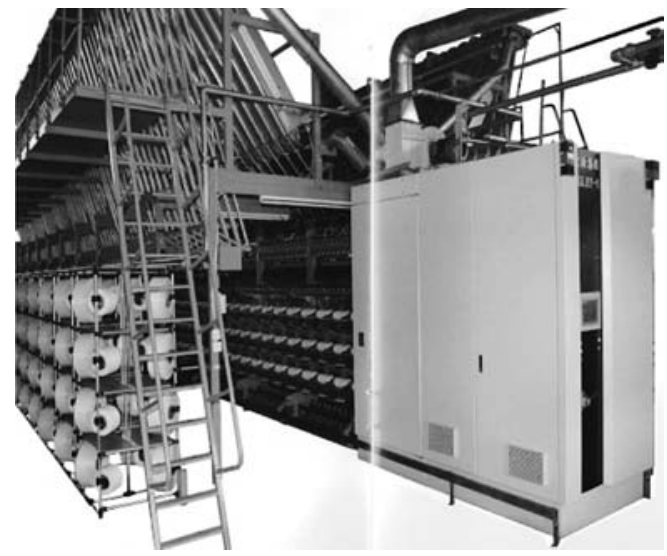

図 $12 \mathrm{HY}-12 \mathrm{~V} / \mathrm{FK} 6, \mathrm{HY}-2$

\section{4 江蘇宏源（中国）}

L側にHY-12V，R側にFK6，HY-2 を配置した，展示 会仕様の両 $\mathrm{V}$ 型 24 錘機を展示していた（図 12）。HY$12 \mathrm{~V}$ 側は 2 次ヒーターのないナイロン機仕様で第 1 フィ ードローラー下から撚止ガイドを介してのスパンデック スとの混瀻加工を行っていた．FK6，HY-2 側ではSZの ポリエステル仕様.FK6の機種名でもわかるように Barmag社の互換部品を数多く取り入れて抢り, 中国メ 一カーの中ではレベルが高く洗練されたイメージがあ る.

\section{5 江蘇海源（中国）}

両側 24 鏵T型機：HFT-1000 と両側 48 鍾機：HFD1200（図 13）の2台を展示していた．HFT-1000はナイ ロン機で片側に 2 軸フリクションを搭載していた．HFD1200 はV型と M 型が片側ずつの展示会用仕様で, 展示 機中で唯一の M 型仕様でもある. V側はシングル仕様, $\mathrm{M}$ 側はSZ仕様であったが M 側は TMT社の $33 \mathrm{H} に$ 近い レイアウトになっている. 出展機の設置スペースとして も出展社の中で最も広く, 様々なレイアウトの機械を複 数台設置していることからも多様なバリエーションへの 対応力の高さをアピールしていることが伺える.

\section{6 浙江越剣機械（中国）}

両側 24 鏵 $\mathrm{T}$ 型機：YJ800DS と両側 48 錘 $\mathrm{V}$ 型機： YJ1200A（図 14）の2台を展示していた，T型機は通路 床下を通して機台外側で卷き取るタイプ．展示機台には

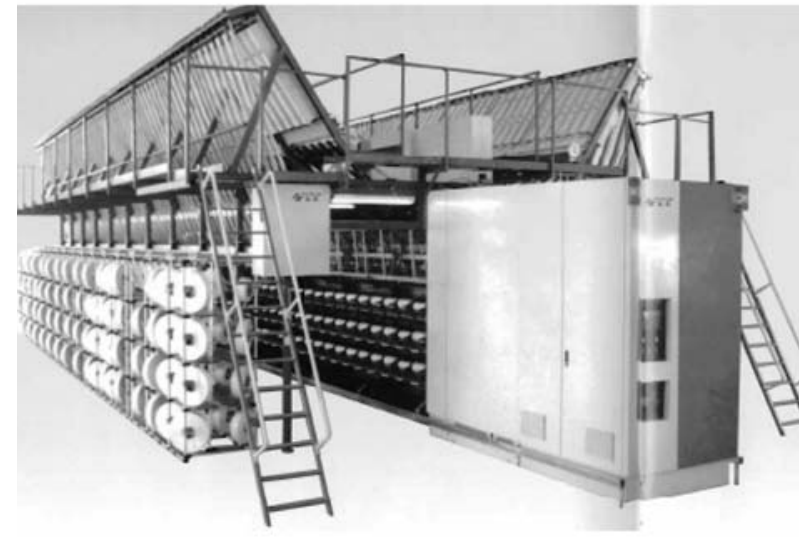

図 13 HFD-1200

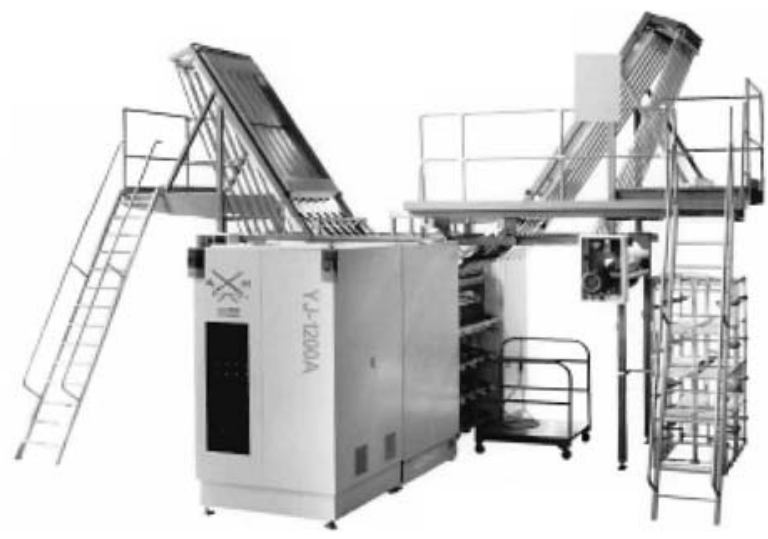

図14 YJ1200A

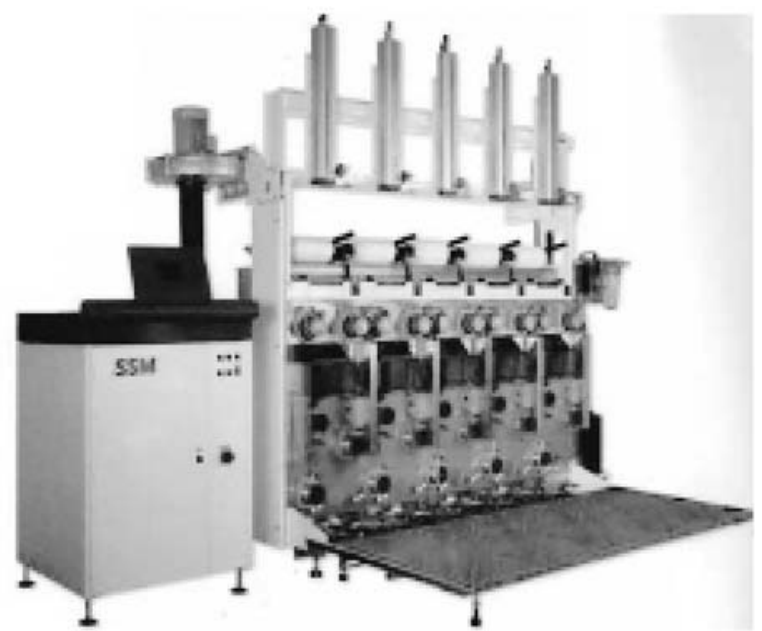

図15 TW2-T

搭載されていなかったがパネルでテンションモニタリン グシステムもアピールしていた。264錘などの多錘仕様 にも対応できるとのことだが単品部品としては全体的に 粗く，技術力はまだまだ後発的な感がある. しかし数々 の展示会を通して年々レベルは上がってきている模様.

【AIR加工機】

\subsection{SSM（スイス）}

機種TW2-Tを6錘機で展示していた（図 15）。コンパ 
クトなターンヒーター（ヒーター内で糸が折り返し本体 長さの約 2 倍の加熱長が取れる）が特徵で往復 $1.5 \mathrm{~m}$ と $3 \mathrm{~m}$ の 2 種類の仕様を搭載していた. FRはゴデットロー ラー仕様で錘によってスパンデックスのエアーカバリン グとホットゴデットローラーでの糸加工を実演してい た.

\subsection{AIKI (日本)}

AT-501 SIAという片側 4錘機を展示していた（図 16）. ジェットボックス内のノズルを交換することでタスラン 加工とスパンデックスのエアカバリング加工が使い分け できるのが特徴である。一つの機種で多様な糸加工に対 応できるように作られている.

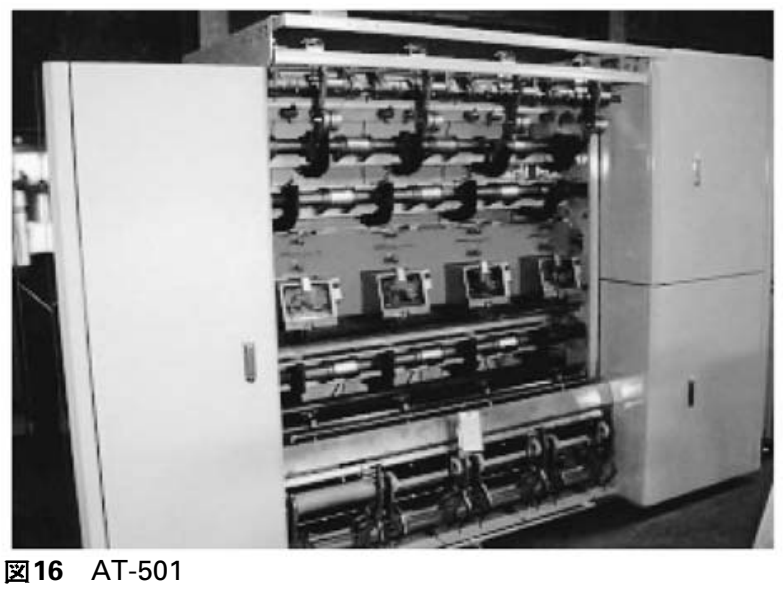

阿部一良 (あべかずよし)

1983 年, 愛媛大学工学部卒, 1985 年, 帝人製機株)（現ナブテスコ）入社, 2005 年, TMT マシナリー(株入社, 現在に至る. 合繊機械の制御開発設計を担当.

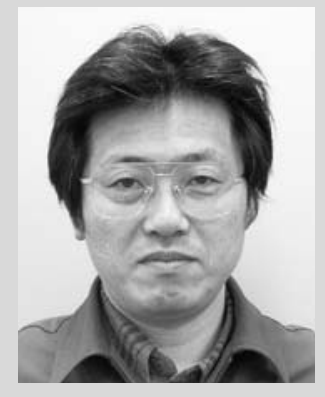

辻 広治 (つじこうじ)

1998 年, 同志社大学工学部卒, 同年, 村田機械(株)入社, 2005 年, TMTマシナリー(株)入社, 現在に至る. 仮撚加工機械設計を担当.

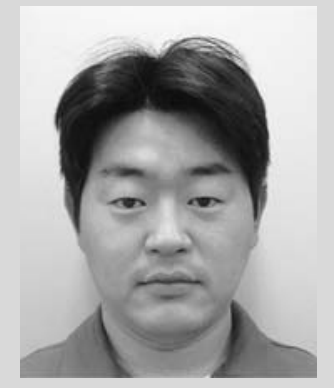

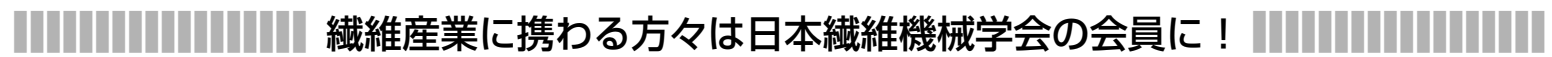

日本䋊維機械学会は, 䋊維産業（繊維製造〜アパレル〜流通）に携わる研究者・技術者の結集体として昭和 23年創立以来, 62年にわたつて産学連携を基調に絶ゆまざる活動を続けております.

また, 本学会内に設置された研究会 (不織布研究会, テクテキスタイル研究会, 繊維リサイクル技術研究会, 織機研究委員会, 染色加工研究会, 生物資源繊維研究会, 織構造プロジェクト研究会, 企業心理亡消費者心理 研究会, コンポジテックス研究会, 染織品と染織文化財研究会, テキスタイル科学研究会, ナノファイバ一研 究会ほか）にもそれぞれの分野の方々が参加されています。

学会活動の活発化や会員の相互啓発は会員が多数であればあるほど, より高まり深くなります.会員各位に おかれましてもお知り合いの方でまだ未入会の方がおられましたら，ぜひで入会をおすすめいただきますよう お願し致します 